\title{
Hull content and chemical composition of whole seeds, hulls and germs in cultivars of rapeseed (Brassica napus)
}

\author{
Patrick Carré^, Morgane Citeau, Gaëlle Robin and Marie Estorges \\ CREOL, 11 rue Monge, Parc Industriel, 33600 Pessac, France
}

Received 8 September 2015 - Accepted 8 March 2016

\begin{abstract}
Objective: To study of the compositional breakdown of seed components between the integument and the germ and its variability according to genetic and environmental factors. Methods: The study used 19 rapeseed lots grown in two areas of contrasted agronomical potential harvested in 2011. Pure fractions of hulls and germs were mechanically separated by centrifuge impacts after freezing the seeds. Chemical composition of the whole seeds and the pure kernel and hull fractions was determined. The results were used to calculate the seed hull content. Results: Hull accounted for $18.2 \%$ of total seed content. Real oil content of the hulls (8.4\% dry basis) was lower than in the literature. Hulls contained $2.9 \%$ of the oil, $11.2 \%$ of the proteins, $73 \%$ of the NDF; $80 \%$ of the ADF, $95 \%$ of the lignin and $6.0 \%$ of the glucosinolates of the whole seed. The percentage of hulls in total seed content shows low variability, although the oil and the protein content of the fractions were significantly affected by cultivar and to a lesser extent by geographic location of the crops. Conclusion: Completely dehulled seeds could result in a meal with $48.3 \%$ protein (dry basis) and low fiber content (10.8\% NDF, 6.6\% ADF, 0.5\% ADL) but higher glucosinolate content (130\% compared to defatted seeds).
\end{abstract}

Keywords: Dehulling / rapeseed / characterization / proteins / oil / hull

\begin{abstract}
Résumé - Teneur en pellicules et composition chimique des graines, pellicules et germes du colza (Brassica napus). Objectifs : Étude de la répartition des composants de la graine entre les téguments et le germe ainsi que leur variabilité selon les facteurs génétiques et environnementaux. Méthodes : Dix-neuf lots de graines issus de 2 lieux de culture ayant des potentiels agronomiques contrastés en 2011 ont été étudiés. Des fractions pures de pellicules et de germes ont été séparées par impacts centrifuges après que les graines aient été congelées. La composition chimique des fractions amandes et pellicules pures a été déterminée. Ces résultats ont servi à calculer le taux de pellicules des graines. Résultats : La teneur en pellicules des graines est de $18,2 \%$. La teneur en huile des pellicules (8,4 \% sur matière sèche) est moindre que dans les données de la littérature. Les pellicules contiennent 2,9\% de l'huile présente dans les graines, $11,2 \%$ des protéines, $73 \%$ du NDF, $80 \%$ de l'ADF, $95 \%$ de la lignine et $6 \%$ des glucosinolates. Le taux de pellicules a une faible variabilité bien que leur teneur en huile et en protéines soit sous l'effet de facteurs génétiques et dans une moindre mesure des conditions du milieu. Conclusion : L'élimination totale des pellicules pourrait aboutir à un tourteau à $48,3 \%$ de protéines (matière sèche) et pauvre en fibres $(10,8,6,6,0,5 \%$ pour NDF, ADF et ADL) mais plus riche en glucosinolates ( $130 \%$ de la valeur des graines déshuilées).
\end{abstract}

Mots clés : Décorticage / colza / caractérisation / protéines / huile / pellicules

\section{Introduction}

Industrial-scale rapeseed dehulling was trialled in France in the 1980s, but the experiment was stopped after a few years and never extended to other oil mills due to significant fats losses in the hull fraction caused by a poor efficiency at purification stage and limited market interest in the dehulled meal itself. However, market demand for proteins has sparked renewed interest in the technology.

Dehulling oilseeds enhances meal quality and - in theory - oil mill crushing capacity, but the technique is rarely applied

\footnotetext{
* Correspondence: carre@cetiom.fr
}

to rapeseed, especially at industrial scale. The main obstacles are the oil-losses in hulls, degradation of the presses performance, and the possible effect of glucosinolates concentrating in dehulled meal. Assessing the economic potential of hull removal hinges on acquiring accurate knowledge of integument and germ masses and their respective compositions. Literature data reported in Table 1 show that values vary widely, especially in terms of protein content of the defatted germs and oil content of the hulls. Most authors except Togni claim that hulls account for around $17-18 \%$ of total seed content. In contrast, reported oil contents for hull and kernel show far more variation, with figures ranging from 10.6 to $16.4 \%$ (dry basis) for 
Table 1. Compositional data on rapeseed hull content and the hull and kernel fractions reported in the literature.

\begin{tabular}{|c|c|c|c|c|c|c|c|c|c|}
\hline \multirow{3}{*}{ Reference } & \multirow{2}{*}{ Hull content } & \multicolumn{4}{|c|}{ Hull composition } & \multicolumn{4}{|c|}{ Kernels composition } \\
\hline & & Oil & Protein & $\mathrm{CF}$ & Ash & \multirow{2}{*}{$\begin{array}{c}\text { Oil } \\
\mathrm{g} / 100 \mathrm{~g} \text { of DM }\end{array}$} & Protein & $\mathrm{CF}$ & \multirow{2}{*}{$\begin{array}{l}\text { Ash } \\
\end{array}$} \\
\hline & \multicolumn{2}{|c|}{$\mathrm{g} / 100 \mathrm{~g}$ of $\mathrm{DM}$} & \multicolumn{3}{|c|}{$\mathrm{g} / 100 \mathrm{~g}$ of $\mathrm{DDM}$} & & \multicolumn{2}{|c|}{$\mathrm{g} / 100 \mathrm{~g}$ of DDM } & \\
\hline Laisney, 1983 & 18 & 10.6 & 18.0 & & & 59.6 & 79 & & \\
\hline Appelqvist and Olhson, 1972 & 16.5 & 16.0 & 18.7 & 34.3 & & 47.1 & 53.6 & 3.0 & \\
\hline Guilbot and Tollier, 1976 & & & 18.1 & 13.7 & 7.7 & & 50.7 & 4.7 & 8.7 \\
\hline Kracht et al., 2004 & $15-22$ & 16.4 & 18.3 & 34.4 & & 55.6 & 48.2 & 3.8 & \\
\hline Burghart et al., 1979 & 17 & & 16.8 & 31.2 & & & 46.0 & 5.3 & \\
\hline Chanet, 1973 & 18.4 & 13.8 & 17.9 & 32.4 & 5.1 & 54.8 & 52.9 & 5.0 & 8.4 \\
\hline Thakor and Sokhansanj, 1997 & & 14.8 & 26.2 & 31.6 & & 51.3 & 60.7 & 6.5 & \\
\hline Togni, 1985 & 12.4 & 13.4 & 17.0 & 27.1 & & 47.8 & 46.4 & 9.7 & \\
\hline Baudet, 1983 & & 12.0 & 18.1 & 28.5 & & 55.3 & 49.4 & 4.9 & \\
\hline Kozlowka et al., 1988 & & 14.0 & 15.1 & 31.9 & 5.2 & 50.4 & 56.4 & 12.0 & 8.0 \\
\hline Mitaru et al., 1984 & & 10.9 & 16.9 & 44.1 & 5.7 & & & & \\
\hline
\end{tabular}

hulls and 47.1 to $59.6 \%$ for germs. Reported protein content of the hulls is around 17-18\% (DDM), except for Thakor and Sokhansanj (who found much higher values). Reported protein content in defatted kernels spans a very large range, from $46 \%$ up to $79 \%$. Reported crude fiber content spans a range of $27.0 \%$ to $44.1 \%$ (DM) in defatted hulls and $3.0 \%$ to $12.0 \%$ in deoiled kernels.

The wide ranges of the figures reported makes it difficult to assess the potential value of dehulled rapeseed meal based on a literature review. We therefore led this study to establish a reliable baseline reference for French rapeseed, with a focus on the hull fraction that requires a sharper characterization due to its potential value as feed or as a biomaterial for non-food uses.

\section{Symbols and abbreviations}

DM: Dry matter basis

SD: Standard deviation

DDM: Defatted Dry matter basis

$\mathrm{CV}$ : Coefficient of variation

GLS: Glucosinolate

NDF: Neutral Detergent Fiber

ADF: Acid Detergent Fiber

ADL: Lignin

CF: Crude Fiber (Wende)

$S S$ : Sum of squares

$S S_{\text {total }}$ : Total sum of squares

$M S$ : Means square

$R^{2}$ : Coefficient of determination

$\phi$ : Proportion of hulls in dry seeds

$C_{j}^{i}$ : Component concentration in the considered fraction $(\mathrm{g} / 100 \mathrm{~g}$ of wet material)

$W_{j}^{i}$ : Share of the component in the considered fraction compared to its total amount in the seed $(\mathrm{g} / 100 \mathrm{~g}$ of wet material).

$i$ : Fractions; $\mathrm{S}=$ seeds, $\mathrm{K}=$ kernels, $\mathrm{H}=$ hulls; $\mathrm{SP}$ : Seed as predicted

$j$ : Components; 1 = oil, $2=$ proteins, $3=$ ash, $4=$ glucosinolates, $5=\mathrm{NDF}, 6=\mathrm{ADF}, 7=\mathrm{DL}, 8=\mathrm{CF}$

$c$ : Cultivar (see identification numbers in Tab. 8)

$n$ : Number of cultivars $(=19)$

$N$ : Number of components measured.

\section{Materials and methods}

\subsection{Rapeseed cultivars}

The study was carried out on 19 lots of seeds harvested in 2011 from two different and contrasted locations in France, i.e. Subdray, stationed on deep and fertile soil, and Surgères, where the soil is shallower and offers less agronomical potential.

\subsection{Seeds conditioning}

Representative seed samples of each cultivar were first cleaned in a lab sorter (Westrup). To improve the purity of the kernel fractions, the samples were first dried at $60^{\circ} \mathrm{C}$ for $2 \mathrm{~h}$, then frozen at $-20{ }^{\circ} \mathrm{C}$ for $24 \mathrm{~h}$. For the hull fractions, the samples were just frozen at $-20^{\circ} \mathrm{C}$ for $24 \mathrm{~h}$.

The improvement brought by this conditioning is illustrated in Figure 1.

\subsection{Dehulling method}

The seeds samples were then dehulled in a customdesigned impactor and sorter (Figs. 2 and 3). Seeds are fed in the center of a rotating disk machined with radiating chanels. Centrifugal force propels the seeds against the wall of the device, and the impact shatters the seeds.

The seeds were impacted twice at $3200 \mathrm{rpm}$ for kernel production and twice at $3000 \mathrm{rpm}$ for hull production. Hulls obtaining was following a softer technical route in order to minimize contamination by kernels residues. Based on a propeller radius of $100 \mathrm{~mm}$, the discharge velocity of the seeds was 44 and $41 \mathrm{~m} \mathrm{~s}^{-1}$ respectively according to calculation with the method of Cooke and Dickens (1971) and assuming that the seeds were sliding rather than rolling with a coefficient of friction $(\mu)$ of 0.33 . The direction of the seeds forms an angle $\beta$ of $54^{\circ}$ with the radius and an angle $\Psi$ of $37^{\circ}$ with perpendicular to the tangent at impact point. The fractions obtained were then separated by air classification and sieving at very slow rate on the sorting apparatus outlined in Figure 2. 

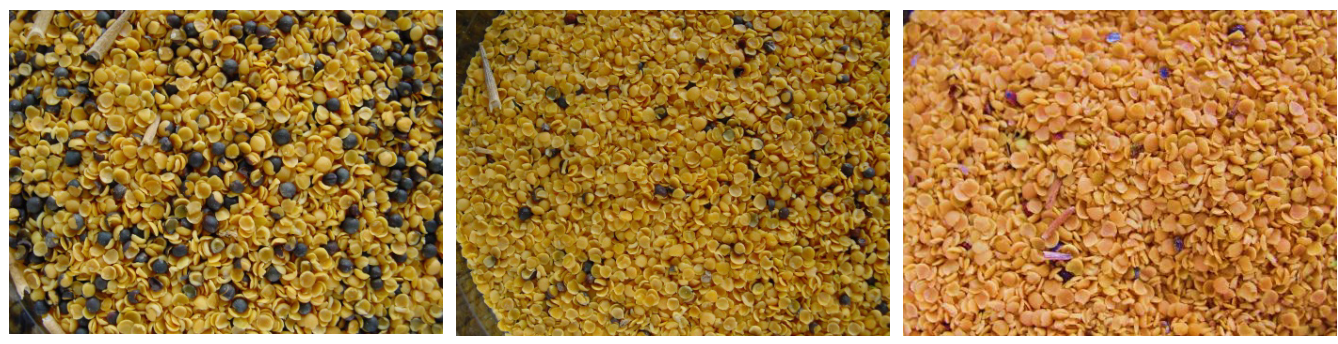

Fig. 1. Improvement of the dehulling enabled by a pre-treatment. (from left to right) Results with unconditioned kernels, frozen kernels, and dried + frozen kernels.

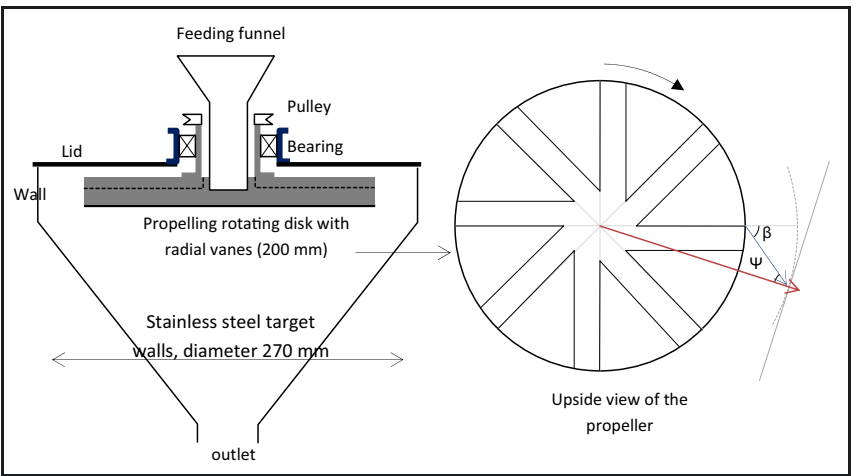

Fig. 2. CREOL impactor.

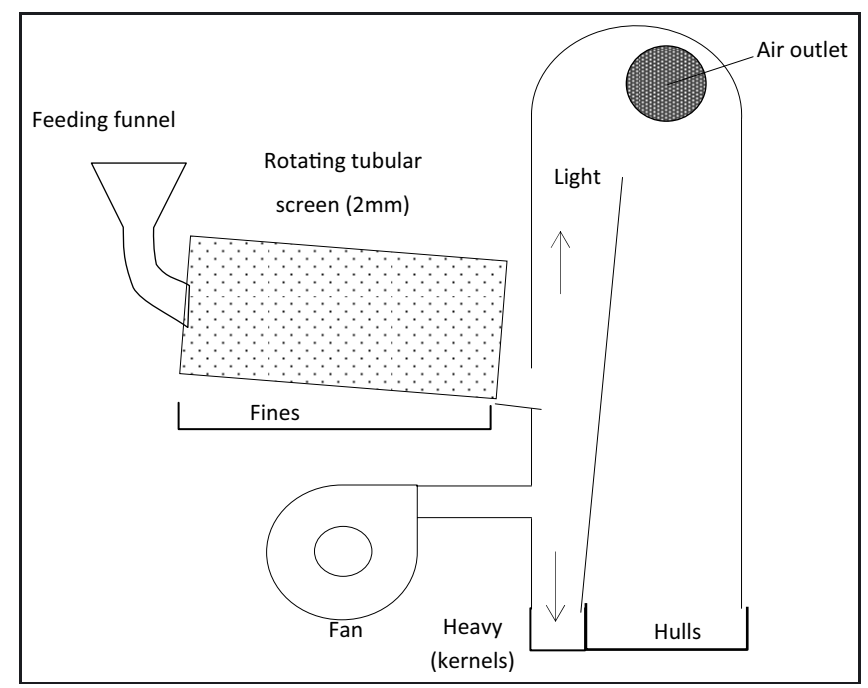

Fig. 3. Lab sorter.

\subsection{Chemical components analysis}

Water, oil, protein, ash, fiber, crude fiber and glucosinolate contents were measured on whole seeds, pure kernel fraction and pure hull fraction.

The methods used were:

- Water: NF V03-909.

- Oil: V03-908 (Soxhlet).

- Total nitrogenous matter: NF V18-120 (Dumas).

- Ash: NF V18-101.
- Van Soest fibers: NF V18-122.

- Crude Fiber = Cellulose (Wende): NF V03-040.

- Glucosinolates: NF V03-918-3.

\subsection{Statistical computations}

Statistical analysis was performed using SAS software version 9.4 (SAS Inc.).

\subsection{Determination of hull content}

$$
\begin{aligned}
S S & =\sum_{j=1}^{8}\left(C_{j \text { measured }}^{S}-C_{j \text { predicted }}^{S}\right)^{2} \\
C_{j \text { predicted }}^{S} & =C_{j \text { measured }}^{H} \phi+C_{j \text { measured }}^{K} \times(1-\phi) \\
\emptyset_{j} & =\frac{C_{j}^{k}-C_{j}^{s}}{C_{j}^{k}-C_{j}^{h}} \\
S S_{\text {total }} & =\sum_{j=1}^{8}\left(C_{j \text { measured }}^{S}-\frac{\sum_{c=1}^{n} C_{j \text { measured }}^{S}}{n}\right)^{2} \\
M S & =\frac{S S}{N} \\
R^{2} & =\frac{\left(S S_{\text {total }}-S S\right)}{S S_{\text {total }}} .
\end{aligned}
$$

The proportion of hulls in the seed $(\phi)$ was established by minimizing the sum of squares of equation (1) using an Excel spreadsheet solver algorithm. The method consists in looking for the value of $\phi$ that give the best fit for the theoretical composition of the seeds according to equation (2). This method presents the advantage of giving more importance to parameters like oil or fiber content that contrast strongly between hulls and kernels. Consequently, experimental error in the measure of the individual parameters has less impact than if $\phi$ was estimated by averaging the value of $\emptyset_{j}$ according to equation (2bis).

The pseudo-coefficient of determination $\left(R^{2}\right.$, Eq. (5)) reflects the improvement in the prediction of each sample composition by using $\phi$ in equation (2) instead of the average composition of the 19 seeds studied. 
Table 2. Chemical composition of whole seeds, kernels and hulls measured.

\begin{tabular}{|c|c|c|c|c|c|c|c|c|c|}
\hline \multirow{2}{*}{ Material } & \multirow{2}{*}{ Stat } & Oil & Protein & Ash & \multirow{2}{*}{$\begin{array}{c}\text { GLS } \\
\mu \mathrm{mol} / \mathrm{g} \text { of DDM }\end{array}$} & NDF & ADF & ADL & $\mathrm{CF}$ \\
\hline & & $\mathrm{g} / 100 \mathrm{~g}$ of $\mathrm{DM}$ & $\mathrm{g} / 100$ & $\overline{\mathrm{DDM}}$ & & \multicolumn{4}{|c|}{$\mathrm{g} / 100 \mathrm{~g}$ of DDM } \\
\hline \multirow{3}{*}{ Kernel } & Mean & 55.97 & 47.82 & 5.48 & 100.38 & 10.81 & 6.60 & 0.47 & 5.80 \\
\hline & SD & 1.56 & 2.52 & 0.34 & 50.93 & 0.61 & 0.51 & 0.13 & 0.26 \\
\hline & $n$ & 20 & 20 & 20 & 6 & 6 & 6 & 6 & 6 \\
\hline \multirow{3}{*}{ Whole seed } & Mean & 48.45 & 38.16 & 5.69 & 77.03 & 29.08 & 21.61 & 9.89 & 15.72 \\
\hline & SD & 1.20 & 2.08 & 0.25 & 37.35 & 1.23 & 1.01 & 0.53 & 0.34 \\
\hline & $n$ & 19 & 19 & 19 & 6 & 6 & 6 & 6 & 6 \\
\hline \multirow{3}{*}{ Hull } & Mean & 8.37 & 14.20 & 5.66 & 9.45 & 70.40 & 57.16 & 31.19 & 38.23 \\
\hline & SD & 0.85 & 0.85 & 0.21 & 4.35 & 2.11 & 2.13 & 1.98 & 1.17 \\
\hline & $n$ & 20 & 20 & 20 & 20 & 20 & 20 & 20 & 20 \\
\hline
\end{tabular}

\section{Results and discussion}

\subsection{Hull content of the seeds}

Table 3 presents the calculated hull contents obtained by the least square method along with some information on the quality of the assessment. When available, 8 triplets of analytical results were used for this assessment, and for the other batches the calculation was done with just oil and protein contents. The average calculated hull content was $18.2 \mathrm{~g} / 100 \mathrm{~g}$ (SD: $1.3 \%, \mathrm{CV}: 7.0 \%, n: 19$ ), which is close to the literature values $(17-18 \%)$.

The variability of hull content was relatively weak and there was no clear relationship between age of the cultivar registration and their hull content. Jet Neuf and Major, which were marketed in the 1970s, have near-average hull content. According to these results, we found no significant correlation between seed oil content and seed hull content $(R=0.27$, $p=0.26)$. However, we found a small but significant correlation between hull content and kernel oil content $(R=0.50$, $p=0.03$ ).

\subsection{Oil content}

The oil content of the hull fraction was low compared to the literature data, i.e. $8.4 \%$ versus an average $13.9 \%$. This difference is explained by the fact that the hulls here were carefully separated from kernel fragments, which also shows that it could be possible to limit oil losses by more efficient hull sorting. However, unlike sunflower seeds, rapeseed coats do contain some oil. They are composed of both tegument and a residual endosperm (Groot and Van Caeseele, 1993) that contains an oil-rich and protein-rich aleuronic layer characterized by thick cell walls (Van Caeseele et al., 1982; Yiu, 1982). Hull (tegument and endosperm) represents $15-20 \%$ of total seed mass (Niewiadomski, 1983). Depending on source cited, oil content is between 10 and $20 \%$ while protein content is between 12 and $20 \%$ of total seed mass (Downey and Bell, 1990), (AFZ, 2014). The purity of the hull fractions has an effect on hull fraction composition: with the Tandem rapeseed variety, Burghart and Evrard found $13.6 \%$ of oil in an average hull fraction and $9.5 \%$ in a more purely-sorted fraction (Burghart and Evrard, 1984). On this basis, we can assume that $30 \%$ of the oil contained in the hull fraction is due to the presence

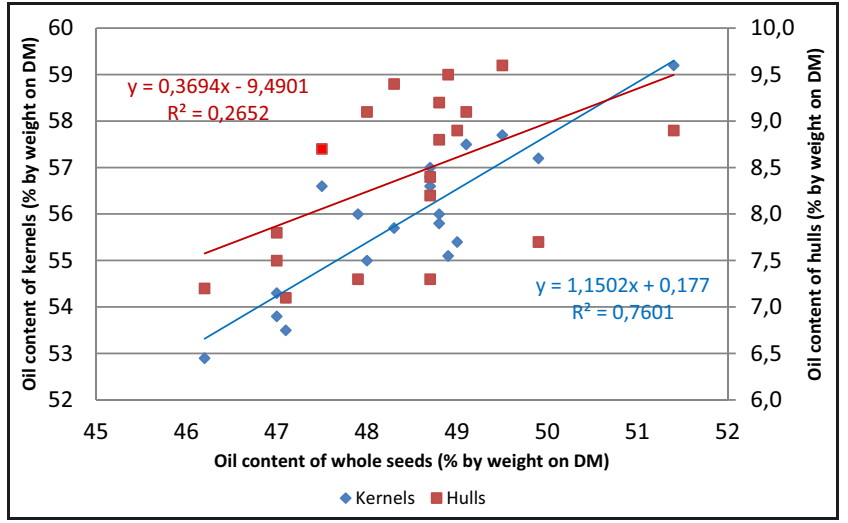

Fig. 4. Relationships between oil content of whole seeds and oil contents of kernel fraction and hull fraction.

of kernel fragments while the other $70 \%$ comes from the endosperm aleurone layer.

The average oil content of the seeds tested was slightly lower than the national average published by the CETIOM in a 2011 survey on seed quality (Garnon, 2011), i.e. $48.45 \%$ versus $48.9 \%$ on DM basis. The age of the studied cultivar (Tab. 3 ) could explain this result, although we did not find a positive effect of the year of registration on oil content of the seeds.

The oil content of the kernel fraction was $56.0 \%$ versus an average $53.4 \%$ in the literature. This result may also be explained by better sorting and the fact that the freezing/thawing preparation may have reduced the adherence of germs and coat.

A consistent correlation was found between seed oil content and kernel oil content $\left(R^{2}=0.76\right)$, but kernel oil content alone cannot explain all the variability in seeds oil which is also determined by hull content and hull oil content. Seed oil content was poorly correlated with hull oil content $\left(R^{2}=0.26\right)$ but the correlation remains statistically significant $(R=0.51$, $p=0.024$ ) (Fig. 4). By contrast, there was no relationship between kernel oil contents and hull oil contents $(R=0.37$, $p=0.10)$.

\subsection{Protein content (expressed on a dry defatted material basis)}

Average protein content in seed was $38.2 \%$ here (Tab. 2), which is lower than the $39.2 \%$ value published in the CETIOM 
Table 3. Kernel and hull contents as determined by the least squares method.

\begin{tabular}{|c|c|c|c|c|c|c|c|}
\hline \multirow[b]{2}{*}{ Variety } & \multirow[b]{2}{*}{ Year registered } & \multicolumn{3}{|c|}{ Subdray } & \multicolumn{3}{|c|}{ Surgères } \\
\hline & & $\begin{array}{c}\text { Hull content } \\
(\mathrm{g} / 100 \mathrm{~g} \text { of } \mathrm{DM})\end{array}$ & $N$ & $R^{2}$ & $\begin{array}{c}\text { Hull content } \\
(\mathrm{g} / 100 \mathrm{~g} \text { of } \mathrm{DM})\end{array}$ & $N$ & $R^{2}$ \\
\hline Amber & 1994 & 16.8 & 8 & 0.998 & 16.3 & 8 & 0.994 \\
\hline ES Astrid & 2003 & 17.0 & 2 & 0.977 & 18.0 & 2 & 0.605 \\
\hline Boral & & 16.3 & 2 & 0.999 & & & \\
\hline Bristol & 1993 & 18.6 & 2 & 0.979 & & & \\
\hline Darmor & 1983 & 18.0 & 2 & 0.898 & & & \\
\hline Gaspard & 1985 & 20.9 & 2 & . & 18.0 & 2 & 0.538 \\
\hline Grizzly & 2003 & 19.0 & 2 & 0.784 & & & \\
\hline Jet9 & 1977 & 17.1 & 8 & 0.987 & & & \\
\hline Major & 1971 & 18.2 & 8 & 0.952 & 18.0 & 8 & 0.987 \\
\hline Navajo & 1992 & 21.2 & 2 & 0.826 & & & \\
\hline Pollen & 1998 & 18.0 & 2 & 0.998 & & & \\
\hline Tapidor & 1989 & & & & 18.9 & 2 & 0.980 \\
\hline Vivol & 1992 & 18.3 & 2 & 0.654 & 18.0 & 2 & 0.951 \\
\hline Warzanwski & . & 18.6 & 8 & 0.992 & & & \\
\hline
\end{tabular}

$N$ : number of analyses used to determine hull percentage, $R^{2}$ : pseudo-coefficient of determination (Eq. (5)).

2011 survey on seed quality (Garnon, 2011). Seed protein content showed greater variability than oil content $(C V>5 \%)$.

Hulls studied here contained less protein than in previous reports, i.e. $14.2 \%$ versus an $18.4 \%$ literature average (excluding Thakor $e t$ al.). Like for oil content, this difference could be explained by better purification than in previous studies. Defatted kernels contained $47.8 \%$ proteins, which equates to $125 \%$ of the whole seed protein concentration.

The protein content of whole seeds is mainly explained by the protein content of the kernels (partial $R^{2}=0.70$ ) and by seed hull content (partial $R^{2}=0.16$ ), but $15 \%$ of the variability remained unexplained in the linear multiple regression carried out using the stepwise procedure in SAS.

Hull protein content and seed protein content did not correlate $(R=-0.25, p=0.29)$. Likewise, seed hull content and hull protein content did not correlate $(R=0.14, p=0.57)$.

\subsection{Ash contents}

There is almost no difference between fractions on ash content, at $4.5 \%, 5.7 \%$ and $5.7 \%$ for the kernels, whole seeds and hulls, respectively. The variability in ash content is relatively low.

\subsection{Glucosinolate contents}

Glucosinolate contents was high in whole seeds $(77 \mu \mathrm{mol} / \mathrm{g}$ DDM) and kernels (100 $\mu \mathrm{mol} / \mathrm{g}$ DDM) (Tab. 2). This is explained the presence of Major, Warsanwski and Jet9, three ancient glucosinolates-rich cultivars. Only the Amber cultivar showed a low glucosinolates content, at $37 \mu \mathrm{mol} / \mathrm{g}$ in seeds and $45 \mu \mathrm{mol} / \mathrm{g}$ in kernels. Average glucosinolates content in the hulls across the 6 samples was $10.6 \mu \mathrm{mol} / \mathrm{g}$.

Glucosinolates are therefore clearly very unevenly split between kernels and hulls, with the vast majority found in kernels which is in accordance with results published by Matthäus (1998).

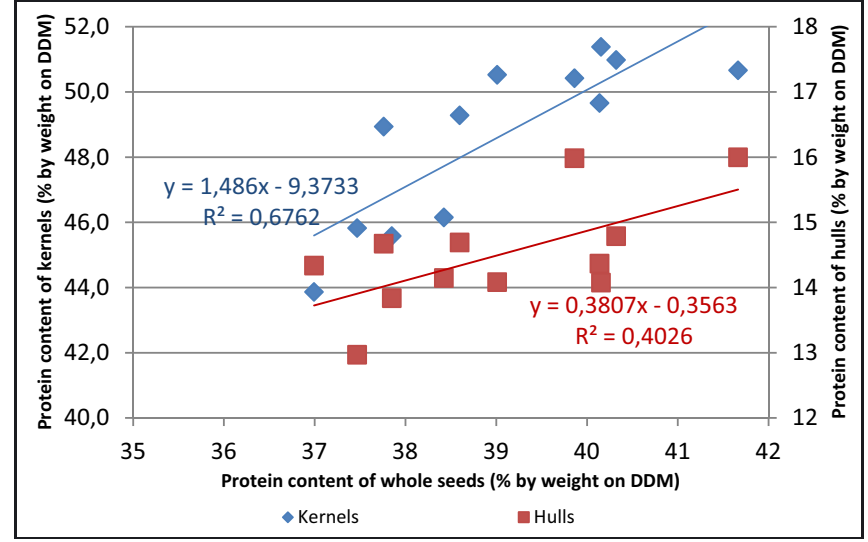

Fig. 5. Relationships between whole-seed protein content and subfraction protein contents.

\subsection{Van Soest Fiber (NDF, ADF, ADL)}

Dry defatted Hulls contained $13.2 \%$ soluble fibers as approximated by NDF-ADF difference, $26.0 \%$ cellulose as approximated by ADF-ADL difference and $31.2 \%$ lignin (ADL). This high lignin content is consistent with literature data, although figures vary greatly depending on sources. Figure 6 charts the distribution of the various fiber categories in our 19 samples.

Hull NDF, ADF and ADL contents are cross-correlated. Hemicellulose content (NDF-ADF) is correlated with the NDF content $(R=0.43, p=0.06)$ but not with ADF content $(R=-0.06)$. Hemicellulose exhibits no statistically significant correlation with cellulose content (ADF-ADL), but this cellulose is positively correlated with the crude fiber value determined according to the Wende method $(R=0.49, p=0.03)$ which is supposed to measure the same thing.

Total fibers content (NDF) reached $70 \%$ on a defatted dry matter basis. Adding ashes and proteins makes it possible to explain $90 \%$ of hull composition. The high fiber content of whole seeds is clearly driven by the presence of hulls. On the 
Table 4. Partial correlation matrix of hull components.

\begin{tabular}{cccccccc}
\hline & & Ash & GLS & NDF & ADF & ADL & CF \\
\hline \multirow{2}{*}{ Oil } & $R$ & 0.60574 & 0.45776 & -0.30921 & -0.20292 & -0.10050 & -0.20018 \\
& Prob. $H_{0}$ & 0.0046 & 0.0424 & 0.1846 & 0.3909 & 0.6733 & 0.3974 \\
\hline \multirow{2}{*}{ Protein } & $R$ & 0.48513 & 0.54294 & -0.85863 & -0.89426 & -0.69842 & 0.44422 \\
& Prob. $H_{0}$ & 0.0301 & 0.0134 & $<0.001$ & $<0.001$ & $<0.001$ & 0.0497 \\
\hline
\end{tabular}

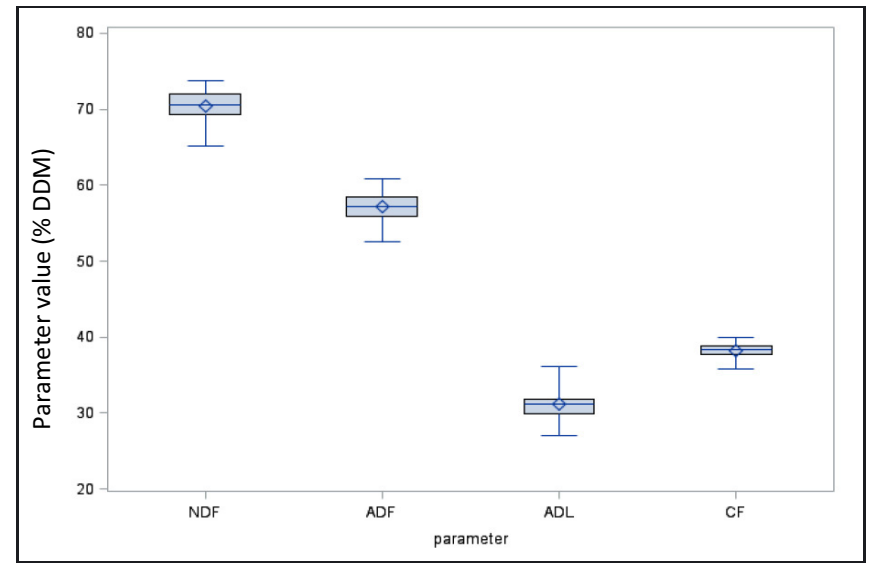

Fig. 6. Distribution of fiber content in hulls $(n=20)$.

other hand, defatted germs are almost lignin-free and contain only $6.2 \%$ cellulose and $4.2 \%$ hemicellulose. The sum of proteins, ashes and NDF accounts for only $64 \%$ of defatted dry kernels. The remaining kernel material should be composed of various carbohydrates, secondary metabolites such as sinapine, and glucosinolates.

\subsection{Crude fiber}

Hull crude fiber contents correlate with ADF fibers $(R=$ $0.86, p<0.0001)$, but the correlation gets weaker $(R=0.523$ and $p=0.015$ ) when tested against Van Soest cellulose (ADFADL). Kernels were found to contain 6.5 times less of this cellulose than hulls.

\subsection{Relationships between hull components}

Note that on top of the correlations indicated above, we found positive relationships between oil and ash contents and between oil and glucosinolates contents (Tab. 4) whereas oil and fiber contents were not correlated.

There is a similar relationship for proteins with ashes and glucosinolates. Given that these 4 components (oil, proteins, ashes and glucosinolates) are likely to be more concentrated in endosperm cells, a greater proportion of endosperm would equate to a greater amount of these components in hulls. Furthermore, protein was negatively correlated to fiber (Fig. 7), which is consistent with this hypothesis.

Two cultivars stretch the dispersion for proteins: Gaspard, which is protein-rich, and Pollen, which is protein-poor.

\subsection{Component distributions in the seed}

Table 5 presents the share of individual components in kernel and hull fractions and the check value according to equations (6) to (9).

$$
\begin{aligned}
W_{j}^{K} & =\frac{C_{j}^{K}}{C_{j}^{S}}(1-\phi) \times 100 \\
W_{j}^{H} & =\frac{C_{j}^{H}}{C_{j}^{S}} \times \phi \times 100 \\
W_{j}^{S P} & =W_{j}^{K}+W_{j}^{H} \\
\text { Recovery } & =\frac{W_{j}^{S P}}{W_{j}^{S}}
\end{aligned}
$$

The recovery of water is not correct, but this is not surprising as the seeds were conditioned before dehulling. Oil in the hull fraction represents just a small proportion of whole-seed oil, so if hulls can be removed without contamination by kernel particles, dehulling would result in limited oil losses.

Recovery of glucosinolates was not perfect but explainable by the lower number of samples studied for seeds and kernels than for hulls and the predominance of high glucosinolates in the seed and kernel samples analysed. If we only factor in the low-glucosinolates cultivars for which we have all the values, the share of glucosinolates in hulls is slightly higher $(6.0 \% \mathrm{vs}$. $3.7 \%)$.

The lignin content is almost exclusively concentrated in hulls, while the cellulose and cellulose-soluble fiber are more evenly shared.

\subsection{Variability in seed fraction compositions}

An analysis of variance (ANOVA) was performed for oil and protein contents. The predictors tested were cultivar the crop location. Of the 14 cultivars available, 6 were grown at both locations. Consequently, ANOVA was only performed on varieties for which we had two observations. Table 6 reports the $R^{2}$ and probability of the $\mathrm{F}$ coefficient associated to each analysis (model without interactions). The coefficient of determination $\left(R^{2}\right)$ reflects the proportion of total variation that is explained by the average of "cultivar" and "location" effects. The $\operatorname{Pr}>F$ indicator is the probability of the $\mathrm{H}_{0}$ hypothesis concerning the $F$ value.

As hull contents showed relatively low variability, we found no significant link between hull contents and the controlled parameters.

Surprisingly, $R^{2}$ values found for kernels and hulls were higher than for whole seeds on both oil content and protein 


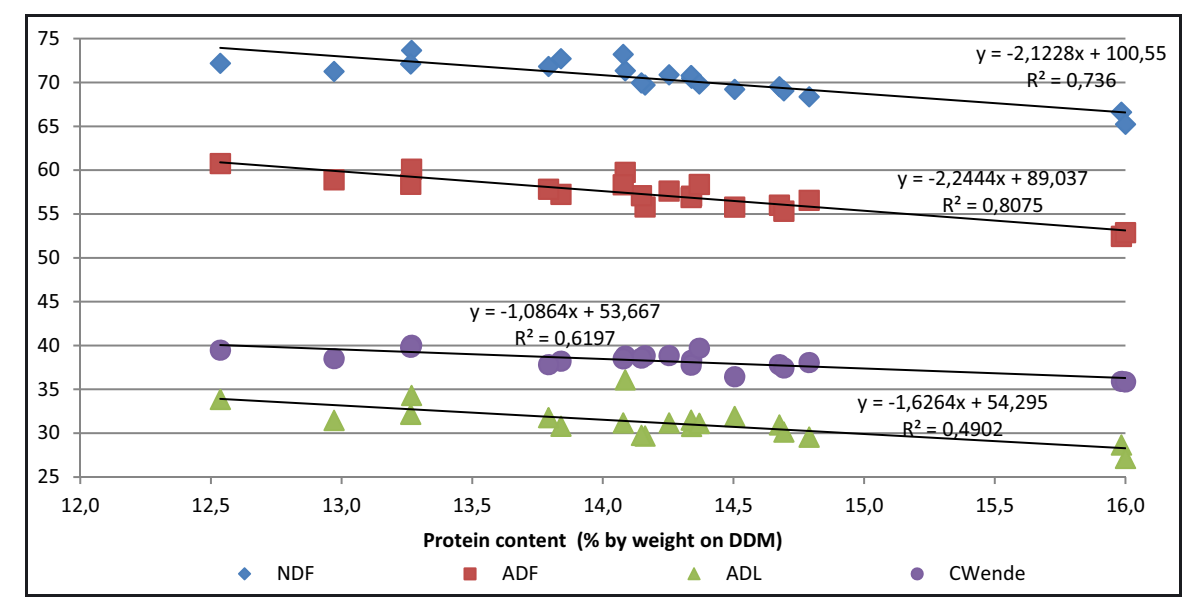

Fig. 7. Relationship between protein and fiber contents of hulls on a defatted dry matter basis.

Table 5. Breakdown of the seed components between hull and kernel fractions.

\begin{tabular}{cccccccccccc}
\hline & Water & Oil & Protein & Ash & GLS & NDF & ADF & ADL & NDF-ADF & ADF-ADL & CF \\
\hline $\begin{array}{c}\text { Kernels } \\
W_{j}^{K}\end{array}$ & $53.7 \%$ & $97.0 \%$ & $89.8 \%$ & $69.7 \%$ & $93.4 \%$ & $26.9 \%$ & $22.1 \%$ & $3.4 \%$ & $40.7 \%$ & $37.8 \%$ & $26.6 \%$ \\
\hline $\begin{array}{c}\text { Hulls } \\
W_{j}^{H}\end{array}$ & $35.3 \%$ & $2.9 \%$ & $11.2 \%$ & $30.0 \%$ & $3.7 \%$ & $73.0 \%$ & $79.7 \%$ & $95.0 \%$ & $53.5 \%$ & $66.7 \%$ & $73.3 \%$ \\
\hline Recovery & $89.0 \%$ & $99.9 \%$ & $101.0 \%$ & $99.7 \%$ & $97.1 \%$ & $99.8 \%$ & $101.8 \%$ & $98.4 \%$ & $94.2 \%$ & $104.6 \%$ & $100.0 \%$ \\
\hline
\end{tabular}

Table 6. Summary of the ANOVAs performed on hull contents and on oil and protein contents of the subfractions.

\begin{tabular}{ccccccccc}
\hline & \multirow{2}{*}{ Hull content } & \multicolumn{2}{c}{ Whole seeds } & \multicolumn{2}{c}{ Kernels } & \multicolumn{2}{c}{ Hulls } \\
\cline { 4 - 10 } & & & Oil content & Protein content & Oil content & Protein content & Oil content & Protein content \\
\hline Cultivar & $R^{2}$ & 0.720 & 0.881 & 0.910 & 0.903 & 0.967 & 0.978 & 0.968 \\
+ location & $P r>F$ & 0.307 & 0.071 & 0.042 & 0.020 & 0.001 & 0.005 & 0.001 \\
\hline Cultivar & $\operatorname{Pr}>F$ & 0.258 & 0.070 & 0.057 & 0.037 & 0.001 & 0.0004 & 0.001 \\
\hline Location & $P r>F$ & 0.414 & 0.120 & 0.036 & 0.009 & 0.022 & 0.159 & 0.128 \\
\hline
\end{tabular}

content. This improvement is not explained by differences in variability of the data except for oil content in hulls. Note that for hulls, location had no significant effect when $R^{2}$ value was strong, which indicates that the oil and protein content of the hulls is mainly related to genetic factors. However, there was a significant "location" effect on kernel fraction, with logically higher oil content at Subdray, which offered greater agronomic potential. Conversely, protein content (\%DDM) was better at Surgères.

Table 7 presents the same ANOVA results as for Table 6 but for hulls only and after integrating the other analytical results. This additional information confirms that genetics is the predominant driver of hull composition. Environment seems to play a role for NDF only.

Table 8 shows a comparison of the means stratified by cultivar. Gaspard, with more oil and proteins, has less fiber and explains a large share of the "cultivar" effect, at least for the fiber and protein contents. In the case of oil, which has the greatest importance in economic terms, there are two groups of three cultivars exhibiting different oil content, which suggests perspectives for minimizing in-hull oil content by means of selection.

\section{Conclusion}

Despite a large panel of rapeseed genotypes and the two contrasted cultivation locations tested, we found relatively little variation in rapeseed hull compositions.

The average protein content found for whole seeds was $38.2 \%$ on defatted dry matter basis. This value is lower than the $39.2 \%$ published in the CETIOM 2011 survey on seed quality (Garnon, 2011). This is important information input for assessing the potential protein content of rapeseed meal after successful dehulling. Combining our results for the repartition of nutrient in the seeds fraction with results of survey we can calculate the potential proteins content of a dehulled rapeseed meal containing $2 \%$ of residual oil and $10 \%$ of water. This potential is $43.4 \%$.

An important result of this work is the better assessment of hull oil content and potential protein content in a well-dehulled meal. In a previous paper (Carré et al., 2015), we assessed rapeseed hull oil content as $9.0 \%$ (dry basis) and the potential protein content in the meal as $43.0 \%$. Our new results are close enough to our previously-assessed figures to validate the conclusions found here. 
Table 7. Summary of the ANOVAs performed on hull composition (12 samples).

\begin{tabular}{cccccccc}
\hline & & Ashes & GLS & NDF & ADF & ADL & CF \\
\hline Cultivar & $R^{2}$ & 0.888 & 0.759 & 0.959 & 0.973 & 0.899 & 0.887 \\
+ location & $\operatorname{Pr}>F$ & 0.028 & 0.154 & 0.003 & 0.001 & 0.022 & 0.029 \\
\hline Cultivar & $\operatorname{Pr}>F$ & 0.020 & 0.119 & 0.002 & 0.001 & 0.017 & 0.023 \\
Location & $\operatorname{Pr}>F$ & 1.000 & 0.690 & 0.026 & 0.611 & 0.323 & 0.229 \\
\hline
\end{tabular}

Table 8. Comparison of the average content of each hull component stratified by cultivar.

\begin{tabular}{ccccccccc}
\hline & Oil & Protein & Ash & GLS & NDF & ADF & ADL & CF \\
\hline Gaspard & $9.6^{\mathrm{a}}$ & $16.0^{\mathrm{a}}$ & $6.0^{\mathrm{a}}$ & $16.8^{\mathrm{a}}$ & $65.9^{\mathrm{b}}$ & $52.7^{\mathrm{b}}$ & $27.9^{\mathrm{b}}$ & $35.9^{\mathrm{b}}$ \\
Amber & $9.2^{\mathrm{a}}$ & $14.2^{\mathrm{b}}$ & $5.8^{\mathrm{ab}}$ & $7.9^{\mathrm{a}}$ & $70.3^{\mathrm{a}}$ & $57.05^{\mathrm{a}}$ & $30.3^{\mathrm{a}}$ & $38.5^{\mathrm{a}}$ \\
Major & $9.0^{\mathrm{a}}$ & $14.6^{\mathrm{b}}$ & $6.0^{\mathrm{a}}$ & $14.5^{\mathrm{a}}$ & $69.7^{\mathrm{a}}$ & $57.2^{\mathrm{a}}$ & $31.0^{\mathrm{a}}$ & $38.8^{\mathrm{a}}$ \\
Vivol & $7.5^{\mathrm{b}}$ & $14.8^{\mathrm{b}}$ & $5.6^{\mathrm{a}}$ & $8.0^{\mathrm{a}}$ & $68.7^{\mathrm{a}}$ & $55.95^{\mathrm{a}}$ & $29.9^{\mathrm{a}}$ & $37.8^{\mathrm{a}}$ \\
Tapidor & $7.5^{\mathrm{b}}$ & $14.2^{\mathrm{b}}$ & $5.7^{\mathrm{a}}$ & $5.6^{\mathrm{a}}$ & $72.1^{\mathrm{a}}$ & $57.95^{\mathrm{a}}$ & $31.2^{\mathrm{a}}$ & $38.7^{\mathrm{a}}$ \\
ES Astrid & $7.4^{\mathrm{b}}$ & $13.4^{\mathrm{c}}$ & $5.5^{\mathrm{b}}$ & $8.9^{\mathrm{a}}$ & $72.0^{\mathrm{a}}$ & $58.05^{\mathrm{a}}$ & $31.2^{\mathrm{a}}$ & $38.4^{\mathrm{a}}$ \\
\hline
\end{tabular}

Means sharing the same subscript letter do not differ significantly according to Student-Newman-Keuls comparisons.

Acknowledgements. This work was performed in partnership with SAS PIVERT within the framework of the French Institute for Energy Transition (Institut pour la Transition Energétique (ITE) PIVERT (www.institut-pivert.com) programme selected as an Investment for the Future ("Investissements d'Avenir") project. This work was supported by the French Government as part of the Investissements d'Avenir programme, under reference ANR-001.

\section{References}

AFZ. 2014. Io7 La Banque de données de l'alimentation animale, Association française de zootechnie.

Appelqvist L, Olhson R. 1972. Rapeseed. Amsterdam: Elsevier.

Baudet J-J. 1983. Valorsation du tourteau de colza par le dépelliclage des graines. In: $6^{\mathrm{e}}$ congrès internationnal sur le colza - Actes du congrès. GCIRC, Paris, pp. 1381-1383.

Burghart P, Evrard J. 1984. Dépelliculage du colza: calcul d'un bilan. Pessac: CETIOM.

Burghart P, Baudet J-J, Evrard J. 1979. Colza: dépelliculage - triage. In: Rapport d'activité 1978-1979. Paris: CETIOM, pp. 34-42.

Carré P, Quinsac A, Citeau M, Fine F. 2015. A re-examination of the technical feasibility and economic viability of rapeseed dehulling. OCL 22: D304.

Chanet M. 1973. Depelliculage des graines de colza. Informations Techniques CETIOM 32: 18-29.

Cooke JR, Dickens JW. 1971. A centrifugal gun for impaction testing of seeds. Trans. A.S.A.E. 14: 147-155.

Downey RK, Bell JM. New development in canola research. In: Sahidi F (ed.), Canola and rapeseed: production, chemistry, nutrition and processing technology. New York: Avi Book by van Nostrand Reinold, 1990.

Garnon. 2011. Qualité des graines de colza - Récolte 2011. Retrieved on 08/16/2012 at http://www.cetiom.fr/uploads/tx_cetiomlists/ QUAL_GRAINES_CO_11_BD.pdf.
Groot EP, Van Caeseele LA. 1993. The development of the aleurone layer in canola (Brassica napus). Revue Canadienne de Botanique 71: 1193-1201.

Guilbot A, Tollier, M. 1976. Extraction et dosage de différents glucides de graines oléagineuses et de leurs dérivés. Rev. Fr. Corps Gras 23: 323.

Kozlowka H, Nowak H, Zadernowski R. 1988. Rapeseed hull fat characteristics. Fat Sci. Technol. 90: 216-219.

Kracht W, Dänicke S, Klüge H, et al. 2004. Effect of dehulling rapeseed on feed value and nutrient digestibility. Arch. Anim. Nutr. 58: 389-404.

Laisney J. 1983. L'huilerie moderne. Paris: CFDT (Cie Française pour le développement des fibres textiles).

Matthäus B. 1998. Effect of dehulling on the composition of antinutritive compounds in various cultivars of rapeseed. Fett/Lipid 100: 295-301.

Mitaru BN, Blair R, Reichert RD, Roe WE. 1984. Dark and yellow rapeseed hulls, soybean hulls and a purified fiber source: Their effects on dry matter, energy, protein and amino acid digestibilities in cannulated pigs. J. Anim. Sci. 59: 1510-1518.

Niewiadomski H. 1983. Rapeseed chemistry and technology. New York: Elsevier Science Publishing.

Thakor N, Sokhansanj S. 1997. Dehulling of canola by hydrothermal treatments \#90-14. In: Research on seed, oil and meal Technologie canola, 11th project report. Winnipeg, Manitoba, Canada: Canola Council, pp. 30-39.

Togni S. 1985. Le dépelliclage du colza. In: Collogue tourteau de colza, "l'enjeu”, 12 June 1985, CETIOM, pp. 219-235.

Van Caeseele LA, Mills JT, Summer M, Gillespie R. 1982. Cytological study of palisade development in the seed coat of Candle canola. Can. J. Bot. 60: 2469-2475.

Yiu S, Poon H, Fulcher RG, Altosaar I. 1982. The microcscopic structure and chemistry of rapeseed ans its products. Food Microstruct. 1: 135-143.

Cite this article as: Patrick Carré, Morgane Citeau, Gaëlle Robin, Marie Estorges. Hull content and chemical composition of whole seeds, hulls and germs in cultivars of rapeseed (Brassica napus). OCL 2016, 23(3) A302. 